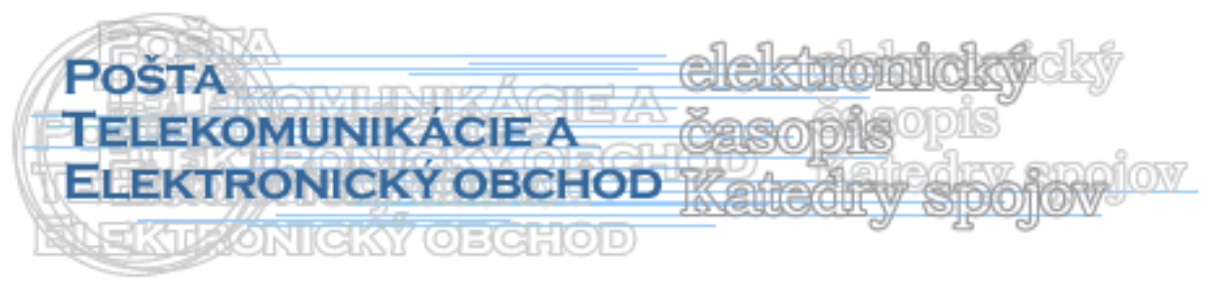

\title{
LIBERALIZÁCIA POŠTOVÉHO TRHU
}

\author{
${\text { Iveta Kremeňová* }{ }^{*} \text { Jana Palková }}^{+}$
}

Rozsah univerzálnych poštových služieb a podmienky ich poskytovania sa v jednotlivých členských štátoch EÚ značne odlišovali a aj kvalita poskytnutých služieb bola vel'mi rozdielna. Preto bolo potrebné prijat' opatrenia na zabezpečenie postupnej a kontrolovanej liberalizácie trhu a primeranej rovnováhy pri dodržaní práv a povinností poskytovatel'ov univerzálnych služieb.

Liberalizácia predstavuje proces odstraňovania prekážok, resp. proces oslobodzovania. Ak hovoríme o liberalizácii poštových služieb, ide o proces odstraňovania prekážok slobodného podnikania na poštovom trhu, pričom slobodné podnikanie treba chápat' ako podnikanie pri dodržiavaní zákonov, morálnych a etických princípov a za transparentných a rovnakých podmienok pre všetkých záujemcov o podnikanie na uvedenom trhu. [1]

\section{Viacstupňový model liberalizácie}

Proces liberalizácie však nemá obmedzit’ nepretržité dodávanie služieb, preto je realizovaný vo viacerých krokoch a bol definovaný Smernicou Európskeho parlamentu a Rady 97/67/ES o spoločných pravidlách rozvoja vnútorného trhu poštových služieb spoločenstva a zlepšovaní kvality služieb. V júni 2002 bola schválená d'alšia smernica 2002/39/ES, ktorou sa dopĺn̆a a mení predchádzajúca smernica, a ktorá sa zaoberá reguláciou postupného otvárania sa poštového trhu.

Táto smernica definovala viacstupňový model liberalizácie poštového trhu vedúceho k postupnému otváraniu sa poštového trhu. V prvej fáze, ktorá sa začala 01.01.2003, sa plánuje pokles existujúcich cenových a hmotnostných hraníc pre vyhradené služby (zníženie hmotnosti na 100 g a zníženie ceny na 3-násobok tarify poskytovatel'a univerzálnej služby pre korešpondenciu prvej hmotnostnej triedy najrýchlejšej štandardnej kategórie). D̆alší stupeň otvorenia sa trhu s d'alším znížením (s poklesom hmotnosti na $50 \mathrm{~g}$ a poklesom ceny na 2,5násobok sadzieb príslušných zásielok je naplánovaný od 01.01.2006. V tomto roku sa má uskutočnit’ štúdia, v ktorej každý členský štát zhodnotí dosah úplného dokončenia vnútorného poštového trhu na univerzálnu službu a potom sa rozhodne o možnej úplnej implementácii

\footnotetext{
* doc. Ing. Iveta Kremeňová, Katedra spojov, Fakulta prevádzky a ekonomiky dopravy a spojov, Žilinská univerzita v Žiline, Univerzitná 1, 01026 Žilina, Slovenská republika, tel.: +421415133108 , fax: +421415655615

e-mail: Iveta.Kremenova@fpedas.utc.sk

+ Ing. Jana Palková, Katedra spojov, Fakulta prevádzky a ekonomiky dopravy a spojov, Žilinská univerzita v Žiline, Univerzitná 1, 01026 Žilina, Slovenská republika, tel.: +421415132023 , fax: +421415655615

e-mail: Jana.Palkova@fpedas.utc.sk
} 
vnútorného trhu poštových služieb v roku 2009.

Univerzálna služba zahŕňa súbor poštových služieb, ktoré je poskytovatel' univerzálnej služby povinný trvalo poskytovat' $\mathrm{v}$ prístupových a kontaktných miestach za rovnakých podmienok, v určenej kvalite a za prijatel'né ceny všetkým užívatel'om každý pracovný deň najmenej s jedným vyberaním a dodávaním denne. [2]

Liberalizácia poštového trhu sa netýka iba znižovania hmotnostných a cenových limitov poštovej výhrady, ale ide aj o liberalizáciu vstupujúcich a vystupujúcich cezhraničných zásielok, liberalizáciu reklamných adresovaných zásielok a liberalizáciu prístupu k sieti.

Pôvodné členské štáty EÚ boli povinné zosúladit' svoju legislatívu so smernicou EÚ 97/67/ES do 10. februára 1999, pričom prístupové krajiny EÚ boli povinné túto smernicu implementovat' najneskôr ku dňu vstupu do Európskej únie a smernicu EÚ 2002/39/ES boli povinné pôvodné členské štáty presadit' do národnej legislatívy najneskôr do 31. decembra 2002, pričom prístupové krajiny EÚ, rovnako ako predchádzajúcu smernicu Európskej únie, boli povinné implementovat' do národnej legislatívy najneskôr do 1. mája 2004. Pôvodné členské štáty mali časovú výhodu oproti prístupovým krajinám na vykonanie liberalizačných krokov. V prístupových krajinách sa postupná liberalizácia uskutočňovala prudšie a nie všetky krajiny mali implementované smernice v príslušných termínoch, niektoré zase prijali liberálnejšie opatrenia ako uvádza smernica $\mathrm{s}$ ciel'om zvýšenia kvality a rozsahu poskytovaných služieb vstupom nových podnikov na trh.

\section{Prehl'ad stavu liberalizácie v krajinách EÚ}

Úplne liberalizovaný trh je vo Švédsku (od roku 1993), vo Fínsku (od roku 1994) a v prístupovej krajine Estónsku (od roku 2002).

Slovinsko znížilo poštovú výhradu na 100 g už v roku 2002. Dánsko od roku 2005 znížilo poštovú výhradu na 50 g. Vel'ká Británia otvorí poštový trh už od roku 2006. Holandsko plánuje zaviest' úplnú liberalizáciu poštového trhu v roku 2007 spolu s Nemeckom. Aj Slovensko plánuje výrazné urýchlenie liberalizácie, ktoré bude založené na zrušení poštovej výhrady v hmotnostnom aj cenovom limite s účinnost'ou od 1. 1. 2007. Pokial' ide o riešenie otázok prístupu k sieti, tento bude zabezpečený od 1. 1. 2009 vzhl'adom na nižšiu prioritu v porovnaní s poštovou výhradou.

Naopak v Pol'sku a na Malte je poštová výhrada vyššia ako vyžaduje smernica EÚ. Pol'sku bola povolená prechodná lehota na zavedenie limitov platných v EÚ. V súčasnosti si uplatňuje pol'ský poskytovatel' univerzálnych služieb poštovú výhradu na jednotlivé služby do hmotnosti 350 g, ale cenový limit je v súlade so smernicou 2002/39/ES, teda 3-násobok príslušnej tarify. Malta mala tiež ku dňu vstupu do EÚ ponechanú výhradu do hmotnosti 350 g a aj jemu zodpovedajúci cenový limit, teda 5-násobok príslušnej tarify.

Vstupujúce cezhraničné zásielky nie sú súčast'ou výhrady iba v Slovenskej republike, kde sa poštová výhrada nevzt’ahuje na korešpondenciu a reklamné adresované zásielky, ak ju vo vnútroštátnom poštovom styku distribuuje poštový podnik, ktorý ju vybral v cudzine [4] a v Českej republike.

Vystupujúce cezhraničné zásielky sú liberalizované v Rakúsku, Belgicku, Nemecku, Dánsku, Francúzsku, Vel'kej Británii, Írsku, Litve, Holandsku, Slovinsku a v Českej republike.

Hromadné zásielky liberalizovalo Španielsko, Slovinsko a Vel'ká Británia.

Určité fázy poštového ret’azca, tzv. „upstream služby“, ako sú napr. vyberanie a preprava zásielok boli už nad rámec poštových smerníc liberalizované v prípade Vel'kej 
Británie a Slovinska. K takémuto kroku je však možné pristúpit', len ak je v krajine zavedený funkčný regulačný mechanizmus prístupu k sieti, ktorý zabezpečí poskytovanie kvalitnej univerzálnej poštovej služby [5].

Pokial' ide o služby ,iné ako univerzálne poštové služby“, t. j. služby, ktoré majú osobitný charakter, vyššiu kvalitu, teda majú pridanú hodnotu, tieto nie sú súčast'ou vyhradenej oblasti len na Cypre, v Nemecku, Dánsku, Španielsku, Francúzsku, Holandsku a Slovensku [5].

\section{Kompenzácia finančných prostriedkov}

Poštová výhrada je jediná forma kompenzácie za povinnost' poskytovat' univerzálnu poštovú službu. Ak krajina pristúpi $\mathrm{k}$ plnej liberalizácii musí mat' vytvorený efektívny legislatívny a regulačný rámec, vrátane modelu na financovanie neprimeraného finančného bremena, ktoré by mohlo vzniknút' poskytovatel'ovi univerzálnej poštovej služby z poskytovania univerzálnej poštovej služby. V prípade zrušenia poštovej výhrady bude potrebné hl'adat' iné spôsoby kompenzácie finančného bremena, ktoré by mohlo vzniknút' poskytovatel'ovi univerzálnej poštovej služby z poskytovania univerzálnej poštovej služby. Jednou z možností kompenzácie, ktorú poskytuje aj smernica EÚ 97/67/ES, je zriadenie kompenzačného fondu.

V súčasnosti kompenzačný fond povolili vytvorit' $\mathrm{v}$ deviatich členských štátoch (Belgicko, Cyprus, Nemecko, Španielsko, Grécko, Taliansko, Lotyšsko, Portugalsko a Slovinsko), avšak v skutočnosti bol vytvorený len v Taliansku, pričom do fondu prispieva iba štát v záujme udržania primeraných cien univerzálnej poštovej služby. Mnohé z členských štátov, ktoré kompenzačný fond majú povolený, sa stretávajú s námietkami o neprimeranosti ustanovení o kompenzačnom fonde. $\mathrm{Aj} \mathrm{z}$ tohto dôvodu je potrebné preskúmat' a hl'adat' aj iné možnosti financovania univerzálnej poštovej služby.

Niektoré členské štáty využívajú aj iné formy kompenzácie finančného bremena z poskytovania univerzálnej služby (napr. SE, BE, FR, UK). Ide najmä o systém poskytovania určitých poštových služieb vo verejnom záujme na základe tzv. „verejných zmlúv“, ktoré zodpovedajú zmluve o výkone služieb vo verejnom záujme v podmienkach SR [6].

Ďalšou možnost'ou, ktorú by mohol využit' poskytovatel' univerzálnej poštovej služby na úplne liberalizovanom trhu poštových služieb je cenová diferenciácia podl'a miesta a spôsobu podania a dodania. Tento spôsob by si však vyžiadal zmenu technológie spracovania poštových zásielok poskytovatel'om univerzálnej poštovej služby čo by malo negatívny dopad pre užívatel'ov poštových služieb, nakol'ko by to viedlo k zvýšeniu cien medzimestských zásielok a zásielok doručovaných do menších obcí; samozrejme výhodou by bolo zníženie cien na lokálnej úrovni, najmä pokial' ide o poštovú službu mestských zásielok a zásielok doručovaných do väčších obcí [5].

Niektorí poskytovatelia univerzálnej poštovej služby v členských štátoch EÚ dostávajú dotácie zo štátneho rozpočtu [5].

\section{Výhody liberalizácie}

Cesta k úplnej liberalizácii je časovo náročný proces, ktorý vyvoláva u poskytovatel'ov univerzálnej poštovej služby tlaky na poskytovanie poštových služieb vyššej kvality za nižšie ceny, núti ich ponúkat' služby s pridanou hodnotou, vyvíjat' produkty ,šité na mieru zákazníka" a tlačí ich k inovatívnemu mysleniu ako aj $\mathrm{k}$ efektívnemu investovaniu do moderných technológií [5].

Výhody, ktoré môžu očakávat’ uživatelia poštových služieb od úplnej liberalizácie trhu 
poštových služieb je najmä širší výber poštových podnikov poskytujúcich poštové služby ako aj možnost' vzniku nových pracovných príležitostí. Na druhej strane však možno očakávat', pokial' ide o poskytovatel'a univerzálnej poštovej služby, naopak zníženie zamestnanosti, ktoré bude vyvolané znížením počtu prístupových miest. Ako potvrdzujú aj skúsenosti v krajinách, v ktorých už je trh poštových služieb plne liberalizovaný, konkurencia, vzhl'adom ku geografickej situácii, nedokáže ponúkat' poštové služby na celom území a teda sa sústred'uje len na najväčšie a teda aj najziskovejšie mestské aglomerácie. V prípade vel'kých miest možno očakávat', že úplná liberalizácia prinesie vyššiu úroveň a kvalitu poštových služieb. Na druhej strane je však potrebné zdôraznit, že vo vidieckych oblastiach a menších mestách sa neočakávajú iniciatívy konkurenčných poskytovatel'ov, naopak možno očakávat' negatívne vplyvy úplnej liberalizácie. V záujme zabezpečenia vyváženého systému je potrebné pristupovat' $\mathrm{k}$ úplnej liberalizácii trhu poštových služieb predvídatel'ným spôsobom a vytvorit' efektívny vyvážený regulačný a legislatívny rámec [5].

Čo sa týka dopytu, spokojnost' spotrebitel'ov s poštovými službami je podl'a súčasnej analýzy verejnej mienky $\mathrm{v}$ porovnaní $\mathrm{s}$ inými službami verejného záujmu vyššia. Vo všeobecnosti je väčšina európskych spotrebitel'ov (74 \%) spokojná s poštovými službami, ktoré im boli poskytnuté. Koneční spotrebitelia v niektorých členských štátoch však vyjadrujú obavy a vnímajú súčasný vývin poštových služieb, oprávnene alebo nie, skôr negatívne. Poštová smernica vyvoláva očakávania, že trh sa otvorí a toto d'alšie otvorenie bude mat' na trh pozitívny vplyv. Poštový trh sa nachádza $\mathrm{v}$ rozhodujúcom štádiu svojho vývoja. Je potrebné uskutočnit' d'alšie kroky na podporu skutočnej hospodárskej sút'aže a zároveň rešpektovat' záujmy konečných spotrebitel'ov; je potrebná inovácia s ciel'om podporit' rozvoj trhu poštového sektoru ako časti podstatne a rýchlo sa meniaceho komunikačného trhu.

\section{Záver}

V správe Európskej komisie Rade a európskemu parlamentu sa uvádza, že reforma poštového sektoru v EÚ je na dobrej ceste. Ešte síce nie je dokončená, ale už priniesla niekol'ko podstatných pozitívnych výsledkov predovšetkým vzhl'adom na kvalitu služieb, zlepšenú efektívnost' podnikov a rozdelenie regulátorov a operátorov.

V súčasnosti sa rieši štúdia „Hodnotenie regulačného modelu európskych poštových služieb“ (riešitel'om je WIK-Consult) a štúdia „Rozvoj hospodárskej sút’aže v európskom poštovom odvetvi'“ (riešitel'om je ECORYS). Závery z týchto štúdií budú podkladom pre vypracovanie štúdie, v ktorej sa pre každý členský štát zhodnotí dopad úplného dokončenia vnútorného poštového trhu v roku 2009 na univerzálnu službu. Vychádzajúc zo záverov tejto štúdie má Európska komisia predložit' Európskemu parlamentu a Rade správu sprevádzanú návrhom, v ktorom bud' potvrdí rok 2009 ako dátum úplného dokončenia vnútorného poštového trhu, alebo na základe záverov štúdie stanoví d’alšie kroky.

\section{Literatúra}

[1] http://www.telecom.gov.sk/pk/050337/vlastnymat.htm

[2] http://www.slposta.sk

[3]

http://www.rokovania.sk/Appl/material.nsf/0/AA7BEA28A0A1FD8DC1256FE9003D462F/\$

FILE/Zdroj.html

[4] http://www.posturad.sk 
[5] http://www.telecom.gov.sk/index/go.php?id=1468

[6] http://www.telecom.gov.sk/index/go.php?id=1674

[7] http://europa.eu.int/eur-lex/lex/LexUriServ/site/sk/com/2005/com2005_0102sk01.pdf 